\title{
30 YEARS OF THE MINERALOCORTICOID RECEPTOR Mineralocorticoid receptor antagonists: 60 years of research and development
}

\author{
Peter Kolkhof ${ }^{1}$ and Lars Bärfacker² \\ 1Drug Discovery, Cardiology Research, Bayer AG, Wuppertal, Germany \\ 2Drug Discovery, Medicinal Chemistry, Bayer AG, Wuppertal, Germany
}

Correspondence should be addressed to P Kolkhof

Email

peter.kolkhof@bayer.com

\begin{abstract}
The cDNA of the mineralocorticoid receptor (MR) was cloned 30 years ago, in 1987. At that time, spirolactone, the first generation of synthetic steroid-based MR antagonists (MRAs), which was identified in preclinical in vivo models, had already been in clinical use for 30 years. Subsequent decades of research and development by Searle \& Co., CibaGeigy, Roussel Uclaf and Schering AG toward identifying a second generation of much more specific steroidal MRAs were all based on the initial 17-spirolactone construct. The salient example is eplerenone, first described in 1987, coincidentally with the cloning of MR cDNA. Its launch on the market in 2003 paralleled intensive drug discovery programs for a new generation of non-steroidal MRAs. Now, 30 years after the cDNA cloning of MR and 60 years of clinical use of steroidal MRAs, novel non-steroidal MRAs such as apararenone, esaxerenone and finerenone are in late-stage clinical trials in patients with heart failure, chronic kidney disease (CKD), hypertension and liver disease. Finerenone has already been studied in over 2000 patients with heart failure plus chronic kidney disease and/or diabetes, and in patients with diabetic kidney disease, in five phase II clinical trials. Here, we reflect on the history of the various generations of MRAs and review characteristics of the most important steroidal and non-steroidal MRAs.
\end{abstract}

\section{Key Words}

- mineralocorticoid receptor antagonists

- spironolactone

- canrenone

- potassium canrenoate

- eplerenone

- apararenone

- esaxerenone

- finerenone

\section{Introduction}

The history of mineralocorticoid receptor antagonists (MRAs) was initially a history of 'aldosterone antagonists (AAs)' as the identification of the first AAs during the 1950s was driven by the goal of identifying inhibitors of aldosterone activity in animals and humans. At that time, the main role of aldosterone was recognized as the control of renal sodium and potassium excretion, although the far-sighted Hans Selye called the mineralocorticoids 'prophlogistic' (Selye 1955). In 1942, he reported that desoxycorticosterone (as the acetate, DOCA), a precursor of aldosterone that was crystallized a decade later, induces nephrosclerosis accompanied by cardiac hypertrophy in animals (Selye 1942). Later, Selye found that application of one of the first AAs, spironolactone, protected rats from aldosterone-induced cardiac necrosis (Selye 1960). This was in the year when the spironolactone was launched as a potassium-sparing diuretic and the pioneering work of Selye on experimental aldosterone-induced inflammation, and fibrosis was not clinically considered for decades.

Years later, but still before the coding DNA of the mineralocorticoid receptor (MR) was cloned, it became clear that AAs block a specific receptor protein that has

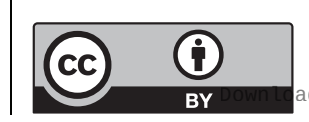

This work is licensed under a Creative Commons Attribution 3.0 Unported License. 
high affinity not only for aldosterone but also for cortisol in humans and corticosterone in rats and mice. Accordingly, AAs were called MRAs. Edelman and coworkers proposed a first model explaining the hormone-receptor activity of adrenal steroid hormones (Feldman et al. 1972) extended later by Corvol and coworkers (Corvol et al. 1981); finally, the publication by Evans' group in 1987 elegantly identified the coding DNA sequence of the intracellular receptor protein that binds different mineralocorticoids and glucocorticoids (Arriza et al. 1987) with high affinity.

The 60 years of MRA research and development comprised three major waves within the pharmaceutical industry: The first basically took place within a single company, Searle Laboratories, which identified steroidbased spirolactone as the first anti-mineralocorticoids shortly after the purification of aldosterone. The second wave (still before the cloning of MR) was driven by the goal of identifying much more specific steroidal antimineralocorticoids, with the main active companies Searle, Ciba-Geigy, Roussel Uclaf and Schering AG. A decade after the cloning of MR, and $\sim 50$ years after Selye's seminal work on the role of aldosterone in experimental renal and cardiac fibrosis, several pharmaceutical companies initiated drug discovery campaigns with the ultimate goal of identifying novel non-steroidal MRAs with defined pharmacokinetic and pharmacodynamic properties for use as safe and efficacious drugs for a broad spectrum of diseases.

One of the fascinating features of these 60 years is that the first MRAs were all discovered and characterized by in vivo experiments in animals and humans, whereas the discovery of novel non-steroidal MRAs employed highthroughput screening (HTS) of millions of compounds in several pharmaceutical companies. Such HTS campaigns for potent and selective MRAs were not possible before cloning of all cDNAs of the members of the steroid hormone-receptor family and their subsequent recombinant expression.

Here, we briefly summarize some characteristics of the most important steroidal and non-steroidal MRAs, including a historical perspective.

\section{Steroidal MRAs (the first $\mathbf{4 5}$ years of MRA R\&D)}

\section{Spironolactone}

Information relating to the project rationale and synthesis efforts which culminated in the discovery of spirolactones (i.e. steroids that contain either a $\gamma$-lactone or a $\gamma$-hydroxy acid function at C-17) at Searle is rather sparse (Sturtevant 1992, Garthwaite \& McMahon 2004).
One chemistry program at Searle was originally focused on 'cardioregulatory agents specifically for treating cardiac arrhythmias' (Fitzgerald \& Fitzgerald 2009), probably based on the attempt to combine parts of the steroidal structures of digitoxin and of progesterone (Garthwaite \& McMahon 2004). The reason for mimicking progesterone was straightforward: Thorn and Engel found progesterone to be natriuretic in dogs (Thorn \& Engel 1938) and Landau and coworkers confirmed this natriuretic activity of progesterone in men (Landau et al. 1955).

After discontinuation of the original chemistry program by the Searle management (for unknown reasons) two biology groups within Searle independently investigated the spirolactone-based compound series in their own established biological assay systems, which were focused on the activity of mineralocorticoids (Sturtevant 1992). The group of Frank Sturtevant explored the compounds in a DOCA-dependent hypertension model, whereas Charles Kagawa, working in the renal labs of Gordon Van Arman, was examining the effects of the compounds in his rat assay of mineralocorticoiddependent sodium retention (Cella \& Kagawa 1957). A particular compound, SC-5233 (3-(3-oxo-17ß-hydroxy4 -androsten-17 $\alpha$-yl)propionic acid $\gamma$-lactone; Fig. 1), demonstrated convincing antagonistic efficacy, which was strictly dependent on the presence of a mineralocorticoid in the models (Kagawa et al. 1959). Moreover, Kagawa and coworkers characterized the compound as a competitive antagonist of aldosterone according to the law of mass action (Kagawa et al. 1957). Sturtevant and Kagawa obviously convinced the management of Searle to initiate clinical trials with the compound (Sturtevant 1992, Fitzgerald \& Fitzgerald 2009). Grant Liddle of Vanderbilt University Medical Center reported the natriuretic activity of SC-5233 in a patient with congestive heart failure and in a patient with Addison's disease. SC-5233 was shown to be natriuretic in the patient with Addison's disease (on a high-sodium diet) only in the presence of DOCA demonstrating that the compound is effective only in the presence of a sodium-retaining steroid, either endogenous or exogenous. Liddle's clinical data and Kagawa's preclinical data were submitted as manuscripts to the journal science in 1957 on August 19 and July 30 respectively and published head to head in one volume of Science in 1957 (Kagawa et al. 1957, Liddle 1957). In the preclinical paper, Kagawa and coworkers described the 19-nor analog of SC-5233, SC-8109 (Fig. 1), to be more potent than SC-5233 on the mineralocorticoid-dependent sodium retention in adrenalectomized rats. Hertz and Tullner subsequently reported that both compounds show

Published by Bioscientifica Ltd. 


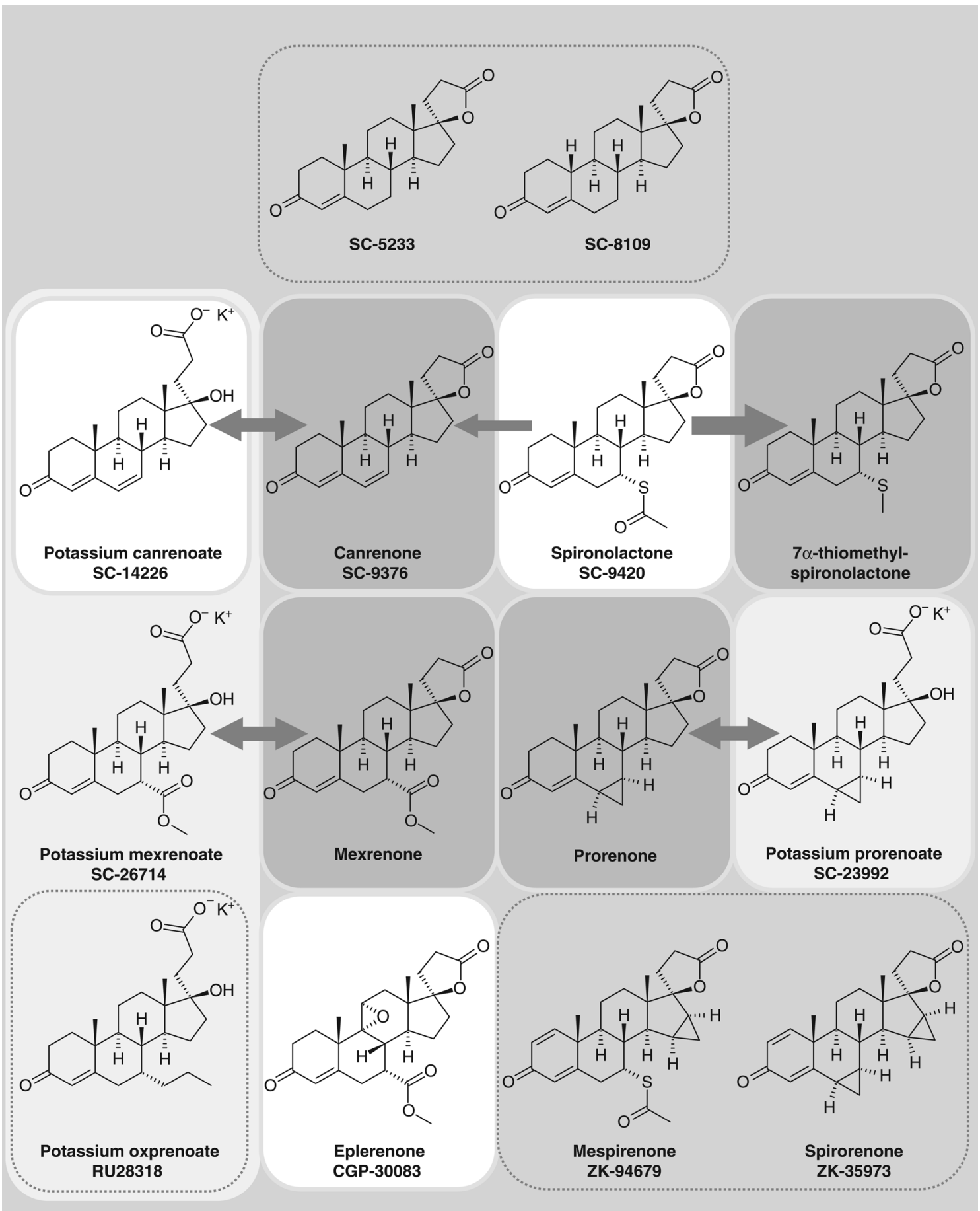

Figure 1

Important steroidal MRAs. Chemical structures of the most important 17-spirolactone derivatives, which were discovered and published between 1957 (beginning on top of the figure) and 1987 are shown. Launched drug compounds are highlighted by a white background. Open-ring potassium salt derivatives are highlighted by a light grey background (note that potassium canrenoate is both, a launched drug and a potassium salt derivative). Active metabolites are highlighted by a darker grey background. Arrows indicate either the generation of respective active metabolites from spironolactone (to different quantitative amounts, indicated by respective arrow sizes) or the equilibrium of the open-ring potassium salts with the respective lactone metabolite. Note the structural similarities of several stacked derivatives, e.g. mexrenone and eplerenone, or spironolactone and mespirenone. 
substantial in vivo progestational activity in the Clauberg assay in estrogen-primed immature rabbits (Hertz \& Tullner 1958) pointing to two different target tissues: the renal tubular apparatus and the endometrium. In the same year, Landau and Lugibihl (1958) published that progesterone is an endogenous antagonist of aldosterone and Liddle coincidentally published the clinical effects of five steroidal derivatives of SC-5233 in edematous patients (Liddle 1958).

The first steroidal spirolactones (Cella \& Kagawa 1957) had only a sufficient exposure in animals and humans when administered parenterally. Therefore, John Cella and his chemistry team of Searle \& Co. introduced chemical modifications with the goal to improve oral bioavailability. They found in a first step that dehydrogenation of saturated bonds leading to $\Delta^{4,6-}$ 3-oxo- and $\Delta^{1,4,6}$-3-oxo-derivatives all possessed enhanced oral activity (Cella \& Tweit 1959). They then added, in a second step, a $7 \alpha$-acetylthio group (among other modifications), as they already knew that the respective $7 \alpha$-acethylthio-derivative of $17 \alpha$-hydroxyprogesterone was more potent than the parent compound when administered parenterally (Cella \& Tweit 1959). The corresponding $\quad 7 \alpha$-acetylthio-17 $\alpha$-hydroxy-3-oxopregn4-ene-21-carboxylic acid $\gamma$-lactone, SC-9420, exhibited oral bioavailability with a 46 -fold higher potency than SC-5233 and was later introduced as spironolactone or Aldactone (Fig. 1) and administered to edematous patients who had not responded to the available standard therapy in a broad dose range up to $2400 \mathrm{mg} /$ day (Garthwaite \& McMahon 2004). A first conference on the clinical use of spirolactones and respective data in individual patients were held in Chicago on October 16, 1958 under the chairmanship of Irwin C. Winter and sponsored by G.D. Searle \& Co. The compiled results of spironolactone in individual patients were sent to the FDA in September 1959, and spironolactone was launched in 1960 as a diuretic for the management of edematous conditions, primary aldosteronism and essential hypertension.

To date, the term 'spironolactone' has been mentioned in more than 8000 articles in PubMed, and several reviews have covered the basic pharmacology and pharmacokinetic properties of spironolactone (Sica 2005, Kolkhof \& Borden 2012, Yang \& Young 2016). The clinical use of spironolactone has also been extended to several indications independent of its 'diuretic' activity, especially after the re-discovery of the experimental pro-inflammatory and fibrotic activities of aldosterone originally described by Selye. The best known example is probably heart failure after Pitt and coworkers demonstrated mortality reduction with a rather low dose of spironolactone given on top of standard of care among patients with severe heart failure in the RALES landmark trial (Pitt et al. 1999); the actual MR ligand in these patients is cortisol, rather than aldosterone, reflecting the absence of the cortisol-converting enzyme

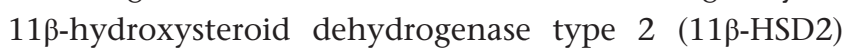
in cardiomyocytes (Funder 2005). Other examples of spironolactone's efficacy in preclinical models of stroke and small clinical trials of CKD let to euphoric editorials calling spironolactone a 'renal aspirin' (Bomback et al. 2009) or even 'the Holy Grail' (Dorrance 2008). On the other hand, there are two major issues associated with the use of spironolactone. The first, binding to the androgen receptor may cause painful gynecomastia and impotence, and binding to the progesterone receptor may cause menstrual irregularities. The second is the risk of developing potentially life-threatening hyperkalemia, especially among patients with reduced kidney function, when given in addition to other blockers of the reninangiotensin system (RAS).

\section{Canrenone, potassium canrenoate and $7 \alpha$-thiomethyl- spironolactone}

Spironolactone can be considered not only as an MRA but also as a pharmacologically active prodrug: it has a short plasma half-life of less than $2 \mathrm{~h}$ and is metabolized in the liver to three major metabolites: Two sulfur-containing metabolites, $\quad 7 \alpha$-thiomethyl-spironolactone (TMS, Fig. 1) and 6 6 -hydroxy-7 $\alpha$-thiomethyl-spironolactone (HTMS) and the major dethioacetylated metabolite canrenone (Fig. 1A), which have mean half-lives in healthy volunteers of $13.8,15.0$ and $16.5 \mathrm{~h}$, respectively (Karim 1978, Garthwaite \& McMahon 2004). Canrenone (Aldadiene, SC-9376), which was long considered to be the major active metabolite of spironolactone, and potassium canrenoate (Soldactone), the potassium salt of the $\gamma$-hydroxy acid derivative of canrenone (Fig. 1), are also marketed as own drug formulation in several countries, e.g. Belgium and Italy. However, TMS was subsequently found to be the main metabolite at steady state after oral application of $100 \mathrm{mg}$ spironolactone per day: peak absolute and relative plasma concentrations of spironolactone, canrenone, TMS and HTMS were found to be 80 (10.3), 181 (23.3), 391 (50.3) and 125 (16.1) ng/ $\mathrm{mL}$ (\%) respectively (Gardiner et al. 1989). Nevertheless, it is remarkable how 'spironolactone focused' several http://joe.endocrinology-journals.org DOI: $10.1530 / J O E-16-0600$ (c) 2017 Society for Endocrinology Printed in Great Britain
Published by Bioscientifica Ltd 
textbooks of pharmacology are as the previously mentioned active metabolites are the major contributors of the pharmacological effects after administration of the prodrug spironolactone in vivo.

Gochman and Gantt first described the generation of canrenone after spironolactone application to a single healthy volunteer already in 1962 (Gochman \& Gantt 1962). Canrenone is the common metabolite of both spironolactone and potassium canrenoate (SC-14266), the ring opened carboxylic acid form (Fig. 1). Potassium canrenoate is the only MRA, which is clinically available as solution for parenteral administration. Nevertheless, despite the structural difference between spironolactone and potassium canrenoate and perhaps because of the common generation of canrenone as an active metabolite, spironolactone and potassium canrenoate are often discussed in the literature as if they are identical compounds. We refer here to two important aspects of both compounds: pharmacokinetic including metabolism and toxicological profile.

The first pharmacokinetic investigations including the determination of metabolites after application of spironolactone in man were conducted by Karim \& Brown (1972) and Sadée and coworkers (Sadée et al. 1973), and thoroughly summarized by Karim (1978) and Overdiek \& Merkus (1987). However, quantitative determination of canrenone in these early studies was limited by a nonspecific fluorometric assay, subsequently improved by the establishment of an HPLC assay. Using this methodology, it was demonstrated that canrenone plasma concentrations were 5 times higher after potassium canrenoate administration than the same dose of spironolactone (Dahlöf et al. 1979). In contrast to the high proportion of canrenone generation after potassium canrenoate application, the canrenone proportion of the metabolites generated after spironolactone administration contributes only to about $15 \%$ after a single dose (Merkus et al. 1983) and about 23\% after multiple doses (Gardiner et al. 1989). These results demonstrate that spironolactone and potassium canrenoate are very different in their metabolism, especially because a number of important sulfur-containing metabolites, i.e. TMS and HTMS, are not generated after potassium canrenoate administration. The elucidation of the different metabolism was also triggered by different toxicological findings with both compounds as outlined below.

The label of Aldactone tablets contains a black box warning, which indicates that spironolactone has been shown to be tumorigenic in chronic toxicity studies in rats (Aldactone NDA 2008). In fact, the origin of this particular safety warning has an interesting history, which includes an admonishing article in the New York Magazine in 1977 also (Vonder Haar \& Miller 1977). There were substantial concerns about the safe use of spironolactone in chronic diseases and accordingly a subsequent decline in prescription rates for about a decade until the late 1980s. Briefly, the chronic safety profile of spironolactone was questioned with the first report of increased numbers of benign testicular adenomas in male rats that received a high dose $(500 \mathrm{mg} / \mathrm{kg})$ of spironolactone over a period of 78 weeks in 1974 (Mayer et al. 1988). In a second 104-week rat study using 10, 30 and $100 \mathrm{mg} / \mathrm{kg} / \mathrm{day}$ of spironolactone, significant increases in hepatocellular adenomas and benign testicular and thyroid adenomas were observed (Aldactone NDA 2008).

Although no tumorigenic or carcinogenic potential was observed with spironolactone in chronic dog and monkey studies in that period (Lumb et al. 1978), additional studies with canrenoate in the early 1980s demonstrated a clear tumor association in rats: Sprague-Dawley rats received potassium canrenoate in doses of 30,90 and $270 \mathrm{mg} / \mathrm{kg} /$ day over a period of 52 weeks in the so-called Hatano study in Japan during 1981. More than 50\% of the animals in the $270 \mathrm{mg} / \mathrm{kg}$ group died due to myelogenous leukemia, tumors of the mammary gland and other neoplasms (Mayer et al. 1988). The study was repeated in the United States with rats receiving 20,50, 125 and $270 \mathrm{mg} / \mathrm{kg}$ over a period of 104 weeks and myelogenous leukemia, tumors of the mammary gland and other carcinomas were statistically significantly increased at a dose of $125 \mathrm{mg} / \mathrm{kg}$ and higher (Mayer et al. 1988). Such tumors were not found with potassium canrenoate in toxicology studies performed in dogs and monkeys. Based on these findings with canrenoate, the Licensing Authority in the U.K. directed manufactures to stop recommending spironolactone for the treatment of hypertension and idiopathic edema in 1988. Accordingly, Spiroprop, a fixed-dose combination of spironolactone and propranolol for treating hypertension was withdrawn (Drug and Therapeutic Bulletin 1988). This led to a thorough reinvestigation of the metabolism of spironolactone and canrenoate, and Searle scientists resolved the phenomenon of the different toxicological findings: potassium canrenoate is metabolized to different epoxy-canrenone derivatives, which were found to be direct mutagens in the mouse lymphoma assay. Importantly, these mutagenic metabolites or their precursor epoxides were not formed from spironolactone
Published by Bioscientifica Ltd 
(Cook et al. 1988, Oppermann et al. 1988). Therefore, the occurrence of myelocytic leukemia in long-term studies with canrenoate in rats can be explained by the formation of these mutagenic metabolites, whereas the generation of benign adenomas by very high doses of spironolactone is most probably related to endocrine pharmacological effects (Mayer et al. 1988).

\section{Potassium prorenoate/prorenone and potassium mexrenoate/mexrenone}

Spironolactone use can be associated with characteristic adverse symptoms such as gynecomastia, which were first described in a letter to The Lancet in 1962 (Smith 1962). Spironolactone possesses clinical progestational and antiandrogenic activity due to interactions with the androgen and progesterone receptors (Huffman et al. 1978, Corvol et al. 1975, Jeunemaitre et al. 1987). Therefore, further drug discovery programs within Searle, CibaGeigy, Roussel Uclaf and Schering AG were initiated in the 1970 s to identify much more specific steroidal MRAs. These programs were also influenced and dependent on novel techniques developed by academic groups, which enabled more direct in vitro investigation of modulating compounds 15 years prior to the cloning of the MR cDNA. Edelman's group isolated and partially purified renal nuclear proteins with postulated mineralocorticoid receptor properties in 1968 (Herman et al. 1968). Using a rat kidney slice technique, Funder and coworkers could follow intracellular binding of aldosterone to a receptor protein in a time-dependent manner (Funder et al. 1972) and established in 1974 a structure-activity relationship (SAR) among 24 spirolactone derivatives by incubating such preparations of rat kidney slices with ${ }^{3} \mathrm{H}$-aldosterone and the different steroidal MRAs (Funder et al. 1974). They discovered that the affinity of spirolactones for the (not yet cloned) receptor is decreased by $\gamma$-lactone ring opening (with the formation of the water-soluble $\mathrm{K}^{+}$salt), $\mathrm{B}$ ring unsaturation at the $\mathrm{C} 6 / \mathrm{C} 7$ position and by $\gamma$-lactone unsaturation. In contrast, affinity was found to be markedly increased by esterification, or thio-esterification, at the C7 position in the B ring (Funder et al. 1974). This was a groundbreaking academic SAR work that supported the parallel medicinal chemistry investigations within the pharmaceutical companies.

It is remarkable that the departments of biological and chemical research of Searle came up with two novel steroidal MRAs almost 20 years after the first series of spironolactones: potassium prorenoate

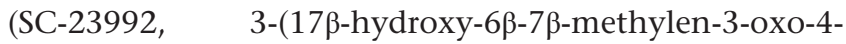
andosten-17 $\alpha$-yl)propionate), the potassium salt of the open lactone corresponding to prorenone (Fig. 1) and potassium mexrenoate (SC-26714, 3-(17 $\beta$-hydroxy, $7 \alpha-$ methoxycarbonyl-3-oxo-4-andosten-17 $\alpha$-yl)propionate) with the corresponding mexrenone (Fig. 1). Prorenoate was found to be 4.6 times more potent than spironolactone in vivo in the Kagawa rat assay using aldosterone as an agonist (Hofmann et al. 1975). As Funder and coworkers (Funder et al. 1976) found coincidentally that prorenoate has a lower affinity in androgen radioreceptor assays than spironolactone, prorenoate was considered as potential spironolactone successor with fewer antiandrogenic side effects (Funder et al. 1976). Claire and coworkers investigated the cellular mode of action and found that $\left[{ }^{3} \mathrm{H}\right]$-labeled prorenone (the active metabolite of prorenoate) blocks nuclear translocation of the (yetto-be cloned and fully purified) aldosterone receptor (Claire et al. 1979).

Results of a head-to-head comparison of prorenoate with spironolactone in fludrocortisonechallenged healthy volunteers were published in 1975 (Ramsay et al. 1975). As a single dose, prorenoate induced significantly more pronounced antikaliuretic activity than spironolactone; results of head-to-head comparison after repeated doses were published in 1982 (McInnes et al. 1982). This study showed that prorenoate was 3.6-fold more potent than spironolactone for urinary sodium excretion and 4.1-fold for elevating plasma potassium in otherwise healthy volunteers. This observation on plasma potassium was the focus of another multiple-dose study among healthy men taking the diuretic metolazone (McInnes et al. 1984). This study showed an estimated potency of prorenoate relative to spironolactone of 5.6-fold in attenuating metolazoneinduced hypokalemia.

The second potential spironolactone successor from Searle was potassium mexrenoate (SC-26714). Doserelated natriuretic responses in animals indicated that potassium mexrenoate was between 2.1 (dog) and 4.5 (rat) times as potent as spironolactone (Hofmann et al. 1977). Although the corresponding lactone mexrenone played an important role later as a structural basis for eplerenone (see below) the development of potassium prorenoate and mexrenoate was not further undertaken by Searle.

\section{Potassium oxprenoate, spirorenone and mespirenone}

Roussel Uclaf identified the open E-ring $7 \alpha$-alkyl spironolactone potassium oxprenoate (potassium $(7 \alpha, 17 \alpha)$ -

Published by Bioscientifica Ltd 
17-hydroxy-3-oxo-7-propylpregn-4-ene-21-carboxylic acid, Fig. 1). The groups of Corvol and Ménard in Paris investigated this MRA in humans (Ulmann et al. 1985). Oxprenoate was tested in comparison with spironolactone or placebo given as single-dose application in healthy volunteers challenged by the application of $9 \alpha$-fluorohydrocortisone, aldosterone or of furosemide (to stimulate the endogenous RAAS). No significant difference was apparent between potassium oxprenoate and spironolactone in all three studies with respect to the urinary $\mathrm{Na}^{+} / \mathrm{K}^{+}$ratio demonstrating that RU 28318 has an antimineralocorticoid effect identical to that produced by the same molar dose of spironolactone. Although not developed further for clinical purposes, the compound, which is actually much better known in the literature as RU28318, is still used in preclinical research due to its relatively good solubility in aqueous solutions enabling, for instance, intracerebroventricular administration in animal studies (Gomez-Sanchez et al. 1992).

Schering AG discovered $17 \alpha$-spirolactones with a 15 , 16- $\beta$-methylene modification. This series contained the most potent steroidal MRAs known to date, among them spirorenone (Bittler et al. 1982, Seifert et al. 1982, Casals-Stenzel et al. 1984) and mespirenone (Losert et al.

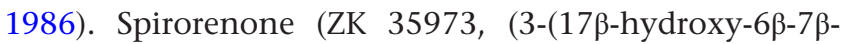
$15 \beta$-16 $\beta$-dimethylene-3-oxo-1,4-androstadiene- $17 \alpha$-yl, Fig. 1) was found to possess in vivo activity on the urinary $\mathrm{Na}^{+} / \mathrm{K}^{+}$ratio on average 8.6 times higher than spironolactone in rats although its affinity for rat renal cytoplasmatic MR preparations was only 0.73 times the affinity of spironolactone (Casals-Stenzel et al. 1984). Spirorenone showed practically no affinity for the rat androgen receptor, but was found to have higher affinity for the progesterone receptor from estrogen-primed rabbit uterus than spironolactone (Laurent et al. 1983). Singledose administration of spirorenone to healthy individuals demonstrated that spirorenone was at least 4 times as potent as spironolactone with respect to urinary sodium excretion (Seifert et al. 1982). It was found that spirorenone generates an active metabolite, 1,2-dihydro-spirorenone in humans (Krause et al. 1983); this compound was later named drospirenone and introduced to the market as the first potent synthetic progestogen exhibiting both antiandrogenic and antimineralocorticoid activity (Muhn et al. 1995). Like spirorenone, it was found to be eight times more potent than spironolactone on the MR in rats (Losert et al. 1985). The development of spirorenone as an MRA, on the other hand, was discontinued.
In search of compounds with increased antimineralocorticoid potency, reduced antiandrogenic potency and reduced or at least unchanged progestogenic potency compared with spironolactone, chemists at

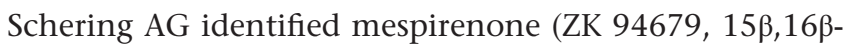
methylene-spironolactone, Fig. 1, Losert et al. 1986). The compound was tested for its natriuretic efficacy vs spironolactone in healthy volunteers and found to be 6-fold more potent (Losert et al. 1986). Although it reached phase II clinical trials, it was discontinued in 1989.

\section{Eplerenone}

Medicinal chemists at Ciba-Geigy synthesized 9-11 $\alpha$-epoxyderivatives of Searle's spironolactone, canrenone, prorenone and mexrenone (de Gasparo et al. 1987) including 9-11 $\alpha$-epoxymexrenone, which was later renamed eplerenone (Fig. 1). This epoxy modification of the steroidal backbone forces the molecule in a more concave form thereby reducing the affinity for the other 3-oxosteroid receptors AR and PR thus yielding more selective steroidal MRAs (Grob et al. 1997). However, eplerenone's improved selectivity goes along with a relatively low in vitro affinity for MR, which is about 40-fold lower than spironolactone (Garthwaite \& McMahon 2004, Hu et al. 2005, Fagart et al. 2010). In vivo, eplerenone compensates for this lower in vitro potency at MR with a higher fraction of bioavailable compound, whereas spironolactone is bound $94 \%$ to human plasma proteins (Chien et al. 1976) and eplerenone's bound fraction is only about 50\% (Inspra Prescribing Information 2002). Eplerenone was investigated in clinical phase I studies in a head-tohead manner with spironolactone published in 1989 (de Gasparo etal. 1989). It demonstrated natriuretic activity after fludrocortisone challenge in heathy volunteers with a rough equi-efficacy at $50 \mathrm{mg}$ to $25 \mathrm{mg}$ spironolactone. The large-scale production of eplerenone was obviously difficult and costly and the compound passed from CibaGeigy to Searle, to Monsanto, to Pharmacia and ultimately to Pfizer (Ménard 2004).

Weinberger and coworkers (Weinberger et al. 2002) showed that $100 \mathrm{mg}$ eplerenone (the maximal approved daily dose for the treatment of hypertension in the United States) given once-daily (OD) or $50 \mathrm{mg}$ twice-daily (BID) to hypertensive patients had an efficacy of 50-75\% compared to $50 \mathrm{mg}$ spironolactone twice daily. These results are in line with the only other published headto-head trial with spironolactone and eplerenone among patients with hypertension and evidence of primary

Published by Bioscientifica Ltd. 
aldosteronism (Parthasarathy et al. 2011). Eplerenone was subsequently investigated in a pivotal clinical phase III in subjects with heart failure after several phase II trials in patients with hypertension. EPHESUS (Eplerenone PostAcute Myocardial Infarction Heart Failure Efficacy and Survival Study) randomized 6642 patients within 14 days of acute myocardial infarction to either eplerenone (mean dose-equivalent was $42.6 \mathrm{mg}$ ) or placebo on top of standard of care including ACEIs/ARBs, betablockers, diuretics and aspirin. After a mean follow-up of 16 months, the primary endpoint, death from any cause or hospitalization for CV events, was significantly reduced by eplerenone (Pitt et al. 2003). This reduction was solely attributed to the prevention of sudden cardiac death. The incidence of serious hyperkalemia $(\geq 6 \mathrm{mmol} / \mathrm{L})$ was significantly higher in the eplerenone group vs the placebo group $(P=0.002)$. Accordingly, eplerenone was launched in the United States for the treatment of chronic heart failure after myocardial infarction in 2002, more than 40 years after spironolactone (Garthwaite \& McMahon 2004, Ménard 2004).

The pharmacokinetic-pharmacodynamic relationship of eplerenone is remarkable and might serve as a role model for MRAs (Kolkhof \& Borden 2012). Eplerenone has no active metabolites and a much shorter half-life than spironolactone's active metabolites: Cook and coworkers (Cook et al. 2003) determined a half-life of $4 \mathrm{~h}$ in steady state after multiple dose applications of $100 \mathrm{mg}$ (which is the approved dose of eplerenone in the U.S. for hypertension). Weinberger and coworkers (Weinberger et al. 2002) demonstrated that the blood pressure-lowering efficacy of eplerenone in hypertensive patients is higher when given twice daily than once daily. Thosar and coworkers (Thosar et al. 2003) demonstrated a natriuretic effect for $\sim 10 \mathrm{~h}$ after a single oral dose of $50 \mathrm{mg}$ eplerenone (the approved OD dosage in HF), and a concomitant short half-life of only $2.9 \mathrm{~h}$ at this dose in healthy subjects. However, despite possessing such a short half-life, eplerenone provides mortality reduction when administered once daily to HF patients (Pitt et al. 2003, Zannad et al. 2011). Therefore, it might be possible that some pharmacodynamic effects mediated by MRAs (e.g. blood pressure control or serum potassium changes) are the consequence of a significant drug exposure over a long period (long half-life, AUC driven), whereas others (e.g., anti-inflammatory, -hypertrophic and -fibrotic effects) are the consequences of relatively short drug exposure (short half-life, $C_{\max }$ driven) triggered by different signaling cascades.

\section{Non-steroidal MRAs (the recent 15 years of MRA R\&D)}

There was a remarkable rise in basic research and small clinical trials on MRAs in several pathophysiological conditions beyond the traditional role of aldosterone in renal sodium/potassium homeostasis since the late 1980s. Weber and coworkers found a marked effect of aldosterone on collagen synthesis in intra-myocardial coronary arteries in the rat (Brilla et al. 1990); Pearce and Funder demonstrated the expression of MR in the heart (Pearce \& Funder 1987), and in the vasculature (Funder et al. 1989). Rocha and coworkers (Rocha et al. 2002) identified vascular inflammation as a potential mechanism of aldosterone-mediated myocardial injury in rats receiving aldosterone chronically in addition to a sodium load, more than 40 years after Selye's seminal work on the role of mineralocorticoids in renal and cardiac fibrosis (Selye 1946). These results stimulated further preclinical and clinical studies on inflammatory and fibrotic diseases including chronic kidney disease, among others. Another trigger for additional $R \& D$ activities on novel MRAs was the issue of hyperkalemia, which was an obligate effect of MR blockade by steroidal MRAs, particularly when given with other RAS blockers to 'real-life' patients, typically with variable degrees of concomitant kidney dysfunction (Juurlink et al. 2004, Svensson et al. 2004, Dinsdale et al. 2005). Interestingly, Taylor and Faloon in 1959 predicted that '...the possibility of initiating potassium intoxication with this regimen (i.e. spironolactone plus potassium supplementation in cirrhotic patients) should be borne in mind' (Taylor \& Faloon 1959), and individual cases of marked hyperkalemia associated with the use of spironolactone were published early on (Herman \& Rado 1966, Pongpaew et al. 1973, Feinfeld $\&$ Carvounis 1978). Accordingly, several pharmaceutical companies initiated drug discovery campaigns with the ultimate goal of identifying novel non-steroidal MRAs with novel physicochemical properties potentially reducing the hyperkalemia risk. We focus here briefly on three novel non-steroidal MRAs, apararenone, esaxerenone and finerenone, which are in several late stage clinical trials.

\section{Apararenone}

Unfortunately, no published preclinical or clinical data are currently available for the non-steroidal MRA apararenone (MT-3995, N-[4-(4-fluorophenyl)-2,2-dimethyl-3-oxo-3,4dihydro-2H-1,4-benzoxazin-7-yl]methanesulfonamide,

Published by Bioscientifica Ltd. 
<smiles>CC1(C)Oc2cc(NS(C)(=O)=O)ccc2N(c2ccc(F)cc2)C1=O</smiles>

Apararenone MT-3995

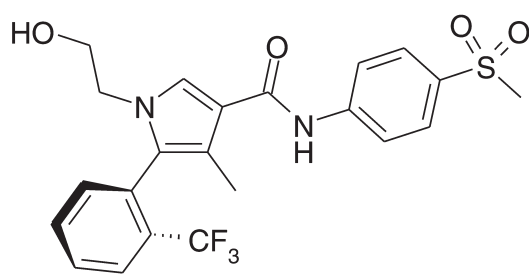

Esaxerenone CS-3150<smiles>COc1cc(C#N)ccc1[C@H]1C(C(N)=O)=C(C)Nc2c(C)cnc(OC)c21</smiles>

Finerenone BAY 94-8862

Figure 2

Novel non-steroidal MRAs in clinical development. Chemical structures of the three clinically most advanced non-steroidal MRAs apararenone, esaxerenone and finerenone are shown (from left to right).

Fig. 2). We can only refer hereto publicly availableinformation from the data bank (clinicaltrials.gov): Mitsubishi Tanabe Pharma was conducting apararenone for the treatment of diabetic nephropathy (DN) in phase II studies in Eastern Europe and Japan and is currently recruiting for an extended treatment study (28 weeks) in patients with DN (excluding patients with an urinary albumin to creatinine ratio (UACR) of $\geq 300 \mathrm{mg} / \mathrm{g}$ ). Recently, a phase II clinical trial has been initiated among patients with non-alcoholic steatohepatitis (NASH) in Japan (Table 1).

\section{Esaxerenone}

Esaxerenone (CS-3150, (5S)-1-(2-hydroxyethyl)-4-methyl$\mathrm{N}$-[4-(methylsulfonyl)phenyl]-5-[2-(trifluoromethyl) phenyl]-1H-pyrrole-3-carboxamide, Fig. 2) is a nonsteroidal MRA, which was discovered by Exelixis and outlicensed to Daiichi Sankyo in 2006. The receptor profile of the compound was published by Arai and coworkers (Arai et al. 2015a): Esaxerenone more potently blocked aldosterone-induced transcriptional activation of human MR in a cell-based assay with an $\mathrm{IC}_{50}$ value of $3.7 \mathrm{nM}$ compared to spironolactone and eplerenone, with $\mathrm{IC}_{50}$ values of 66 and $970 \mathrm{nM}$ respectively. Esaxerenone also showed at least a 1000-fold higher selectivity for MR over other steroid hormone receptors in vitro, a long half-life and a more pronounced antihypertensive activity induced by DOCA/salt-loading to rats than spironolactone or eplerenone (Arai et al. 2015a). Chronic treatment of Dahl salt-sensitive hypertensive rats demonstrated a dose-dependent antihypertensive effect of esaxerenone with an equivalent reduction of blood pressure with a low dose of esaxerenone $(0.5 \mathrm{mg} / \mathrm{kg})$ to that of spironolactone $(100 \mathrm{mg} / \mathrm{kg})$ and eplerenone $(100 \mathrm{mg} / \mathrm{kg})$.
Similarly, esaxerenone also reduced proteinuria and renal hypertrophy with superior potency to that of spironolactone and eplerenone, which demonstrated only partial cardiorenal protection in this study (Arai et al. $2015 b$ ). Furthermore, esaxerenone not only prevented but also ameliorated hypertension and renal injury in DOCA rats (Arai et al. 2016).

In January 2015, Daiichi Sankyo announced the start of two different phase II studies: a dose-finding study in Japanese patients with type 2 diabetes mellitus (T2DM) and microalbuminuria and a study to evaluate the efficacy and safety of esaxerenone in Japanese patients with hypertension. Although no data from these studies have been published so far in a scientific journal, some preliminary clinical data were presented recently in an investor presentation published on Daiichi Sankyo's web site (Daiichi Sankyo's FY2016 Q2 earnings call, November 1, 2016). In September 2016, Daiichi Sankyo announced it is undertaking a phase 3 pivotal trial (ESAX-HTN) to evaluate esaxerenone as a treatment for essential hypertension in Japanese patients. The primary objective is non-inferiority of an antihypertensive effect in comparison to eplerenone $(50 \mathrm{mg})$ in a 12 -week study among 930 patients. Several smaller local studies with blood pressure determinations as primary outcome parameter in different patient populations are currently recruiting patients (Table 1).

\section{Finerenone}

Several reviews have already summarized preclinical and clinical data of finerenone (Kolkhof et al. 2015, 2016, Liu et al. 2015, Bramlage et al. 2016, Gomez-Sanchez 2016, Haller et al. 2016, Yang \& Young 2016), and we will

Published by Bioscientifica Ltd. 
Table 1 Current late stage clinical studies with non-steroidal MRAs.

\begin{tabular}{|c|c|c|c|c|c|}
\hline NCT\# & $\begin{array}{l}\text { Study } \\
\text { completion }\end{array}$ & Phase & No. enrolled & Locations & Study name/condition \\
\hline \multicolumn{6}{|l|}{ Apararenone } \\
\hline NСT02923154 & Oct 2017 & Phase 2 & 40 & Japan & $\begin{array}{l}\text { An exploratory study of MT-3995 in patients with non-alcoholic } \\
\text { steatohepatitis (NASH) }\end{array}$ \\
\hline NCT02676401 & Apr 2018 & Phase 2 & 280 & Japan & $\begin{array}{l}\text { An extended treatment study of MT-3995 in patients with } \\
\text { diabetic nephropathy }\end{array}$ \\
\hline \multicolumn{6}{|l|}{ Esaxerenone } \\
\hline NCT02885662 & Dec 2017 & Phase 3 & 40 & Japan & $\begin{array}{l}\text { A study of CS-3150 to evaluate efficacy and safety in patients } \\
\text { with primary aldosteronism }\end{array}$ \\
\hline NCT02808026 & Dec 2017 & Phase 3 & 20 & Japan & $\begin{array}{l}\text { A study to evaluate efficacy and safety of CS-3150 in Japanese } \\
\text { patients with severe hypertension }\end{array}$ \\
\hline NCT02807974 & Dec 2017 & Phase 3 & 50 & Japan & $\begin{array}{l}\text { A study of CS-3150 to evaluate efficacy and safety in } \\
\text { hypertensive patients with type } 2 \text { diabetes and albuminuria }\end{array}$ \\
\hline NCT02807987 & Dec 2017 & Phase 3 & 50 & Japan & $\begin{array}{l}\text { A study of CS-3150 to evaluate efficacy and safety in } \\
\text { combination with ARB or ACE inhibitor in hypertensive } \\
\text { patients with moderate renal impairment }\end{array}$ \\
\hline NCT02848170 & Dec 2017 & Phase 3 & 40 & Japan & $\begin{array}{l}\text { Phase } 3 \text { study to examine the relation between } \\
\text { antihypertensive effect and baseline factors exploratively, } \\
\text { compared to olmesartan medoxomil in patients with essential } \\
\text { hypertension }\end{array}$ \\
\hline NCT02722265 & Dec 2017 & Phase 3 & 360 & Japan & $\begin{array}{l}\text { Open-label, multicenter, interventional, dose titration study to } \\
\text { assess the long-term study of CS-3150 } 2.5 \mathrm{mg} \text { and } 5 \mathrm{mg} \text { alone } \\
\text { as monotherapy or in combination with other } \\
\text { antihypertensive drug in Japanese patients with essential } \\
\text { hypertension }\end{array}$ \\
\hline NCT02890173 & Dec 2017 & Phase 3 & 930 & Japan & $\begin{array}{l}\text { A double blind study of CS-3150 to evaluate efficacy and safety } \\
\text { compared to eplerenone in patients with essential } \\
\text { hypertension (ESAX-HTN Study) }\end{array}$ \\
\hline \multicolumn{6}{|r|}{ 19קc } \\
\hline NCT02545049 & Feb 2019 & Phase 3 & 6400 & Global & $\begin{array}{l}\text { A randomized, double-blind, placebo-controlled, parallel- } \\
\text { group, multicenter, event-driven phase } 3 \text { study to investigate } \\
\text { efficacy and safety of finerenone on the reduction of } \\
\text { cardiovascular morbidity and mortality in subjects with type } 2 \\
\text { diabetes mellitus and the clinical diagnosis of diabetic kidney } \\
\text { disease in addition to standard of care (FIGARO-DKD) }\end{array}$ \\
\hline NCT02540993 & May 2019 & Phase 3 & 4800 & Global & $\begin{array}{l}\text { A randomized, double-blind, placebo-controlled, parallel- } \\
\text { group, multicenter, event-driven phase } 3 \text { study to investigate } \\
\text { the safety and efficacy of finerenone, in addition to standard } \\
\text { of care, on the progression of kidney disease in subjects with } \\
\text { type } 2 \text { diabetes mellitus and the clinical diagnosis of diabetic } \\
\text { kidney disease (FIDELIO-DKD) }\end{array}$ \\
\hline
\end{tabular}

highlight here only some specific features of this novel non-steroidal MRA.

A cluster of dihydropyridines (DHPs) acting as MRAs in vitro were identified in an ultrahigh throughput screening program of $\sim 1,000,000$ compounds at Bayer (Ergueden et al. 2005). This finding was very surprising as DHPs constitute the known class of L-type calcium channel blockers (CCB) like nifedipine. Chemistry programs within Bayer, Pfizer and Merck led to potent and specific MRAs with and without additional L-type calcium channel activity (Brandish et al. 2009, Arhancet et al. 2010, Fagart et al. 2010, Bärfacker et al. 2012).

Chemical optimization of DHP-based compounds led to a novel series of heterobicyclic analogs of naphthyridine derivatives (Bärfacker et al. 2012). The dihydronaphthyridine finerenone (previous nomenclature BAY 94-8862, Fig. 2) was identified as a potent MRA with excellent selectivity vs all other steroid hormone receptors as well as 65 important receptors and ion channels including the L-type $\mathrm{Ca}^{2+}$ channel (Bärfacker et al. 2012, Pitt et al. 2012). Thus, finerenone is at least as potent as spironolactone and even more selective (at least 500fold toward MR) than eplerenone. Table 2 shows that finerenone more potently blocks MR in a functional cellbased assay system than spironolactone and eplerenone independent of MR agonist (i.e. aldosterone, cortisol, coticosterone or DOCA). Finerenone was shown not only to block wild-type MR in vitro but also the gain-offunction S810L MR mutant (Amazit et al. 2015), which is the cause for early-onset hypertension in men and

Published by Bioscientifica Ltd. 
Table 2 In vitro potency of spironolactone, eplerenone and finerenone vs different MR agonists in a functional cell-based MR assay.

\begin{tabular}{|c|c|c|c|}
\hline \multirow[b]{2}{*}{ Agonist } & \multicolumn{3}{|c|}{ Antagonist } \\
\hline & $\begin{array}{l}\text { Spironolactone } \\
\qquad \mathrm{IC}_{50}(\mathrm{nM})\end{array}$ & $\begin{array}{l}\text { Eplerenone } \\
\qquad \mathrm{I}_{50}(\mathrm{nM})\end{array}$ & $\begin{array}{r}\text { Finerenone } \\
\mathrm{IC}_{50}(\mathrm{nM})\end{array}$ \\
\hline Aldosterone & 24 & 990 & 18 \\
\hline Cortisol & 19 & 360 & 5 \\
\hline Corticosterone & 41 & 940 & 24 \\
\hline DOCA & 114 & 1970 & 46 \\
\hline
\end{tabular}

Half-maximally inhibitory concentrations $\left(\mathrm{IC}_{50}\right)$ of MRAs were determined in a functional cell-based transactivation assay based on $\mathrm{CHO}-\mathrm{K} 1$ cells stably expressing the ligand binding domain of MR as described by Fargart and coworkers (Fargart et al. 2010). The IC ${ }_{50}$ values determined vs aldosterone as agonist were taken from Pitt and coworkers (Pitt et al. 2012). All other $I C_{50}$ values of the three MRAs were determined in parallel investigations performed in duplicate. The agonist concentrations used were $1 \mathrm{nM}$ for aldosterone and corticosterone and $10 \mathrm{nM}$ for cortisol and DOCA. The GraphPad Prism software (version 3.02, GraphPad Software) was used for curve fitting and calculation of $\mathrm{IC}_{50}$ values.

gestational hypertension in women (Geller et al. 2000). Progesterone and both steroidal MRAs, spironolactone and eplerenone, paradoxically activate this S810L MR mutant (Geller et al. 2000, Amazit et al. 2015). Using an automated HTS microscopy of MR subcellular distribution, it was demonstrated that finerenone delays aldosterone-induced nuclear translocation MR more efficiently than spironolactone (Amazit et al. 2015). Moreover, chromatin immunoprecipitation (ChIP) assays showed that finerenone and spironolactone differentially affect the recruitment of the transcriptional cofactor SRC-1 on a MR target promoter. Although finerenone acts as an inverse agonist, i.e., reducing SRC- 1 recruitment even in the absence of aldosterone at the promoter of the SCNN1A gene, spironolactone acts as a partial agonist, i.e., promoting SRC-1 recruitment but to a lesser extent as aldosterone (Amazit et al. 2015). These results show that structurally different MRAs can lead to a different pharmacology. In contrast to spironolactone and eplerenone, the non-steroidal MRAs BR-4628 and finerenone are 'bulky-passive' antagonists (Fagart et al. 2010, Bärfacker et al. 2012, Amazit et al. 2015). Binding of 'bulky' non-steroidal MRAs probably cause a protrusion of helix 12 in MR's C-terminal-activating function 2 domain, and as a consequence, an unstable receptorligand complex, which is unable to recruit coregulators (Kolkhof \& Borden 2012).

The non-steroidal structure of finerenone does not only influence the binding mode within MR, but especially determines the physicochemical properties like lipophilicity and polarity, which have a strong impact on plasma protein binding, transport, tissue penetration and distribution. The steroidal MRAs are 6- to 10-fold more lipophilic than finerenone, whereas the latter exhibits higher polarity than the steroidal MRAs (Kolkhof et al. 2015). Quantitative wholebody autoradiography with $\left[{ }^{14} \mathrm{C}\right]$-labeled finerenone demonstrated a balanced distribution of finerenone into cardiac and kidney tissues of healthy rats, which is in clear contrast to the respective distribution pattern of spironolactone and eplerenone in rodents (Kolkhof et al. 2014). Experiments using radioactively labeled eplerenone demonstrated at least a 3-fold higher accumulation of the drug equivalent concentration in the kidneys compared with heart tissue in rats, whereas high drug equivalent concentrations (original drug plus metabolites) after administration of radioactively labeled spironolactone were detected within the kidneys, but the whole radioactivity in cardiac tissue was below the detection limit in a similar study in mice (reviewed in Kolkhof \& Borden 2012).

Finerenone reduced cardiac hypertrophy, pro-B-type natriuretic peptide (BNP) and proteinuria more efficiently than eplerenone when directly comparing equinatriuretic doses (Kolkhof et al. 2014). Finerenone reduced systolic blood pressure (SBP) values in DOCA/salt rats only at the highest investigated dose of $10 \mathrm{mg} / \mathrm{kg}$, although almost all functional parameters were improved with the dose of $1 \mathrm{mg} / \mathrm{kg}$ that had no significant influence on blood pressure. Systolic blood pressure in animals treated with $10 \mathrm{mg} / \mathrm{kg}$ finerenone was significantly lower in comparison to animals treated with $100 \mathrm{mg} / \mathrm{kg}$ eplerenone in a head-to-head manner. In a mouse model of pressure overload-induced HF treatment with finerenone compared head-to-head with eplerenone resulted in a more pronounced prevention of myocardial hypertrophy (Grune et al. 2016). These head-to-head observations contributed to the hypothesis that use of finerenone is either associated with a more pronounced antihypertrophic/anti-fibrotic efficacy at a given comparable risk for developing hyperkalemia or with a reduced risk of developing hyperkalemia at a given comparable anti-hypertrophic/-fibrotic efficacy (Bauersachs 2013, Naegele et al. 2016). To test this hypothesis, finerenone was tested head-to-head vs spironolactone among patients with chronic heart failure and concomitant CKD (Pitt et al. 2012). It was found that once-daily oral administration of 5 and $10 \mathrm{mg}$ of finerenone were at least as effective as spironolactone ( 25 or $50 \mathrm{mg} /$ day) in decreasing BNP, NT-pro-BNP and urinary albumin, but were associated with significantly lower increases in serum potassium, a

Published by Bioscientifica Ltd. 
significantly lower incidence of hyperkalemia as well as a lower incidence of worsening renal function (Pitt et al. 2013). However, the reduction in SBP and the rise in serum aldosterone levels in patients receiving finerenone 5 and $10 \mathrm{mg}$ OD were smaller than those observed in patients receiving spironolactone in ARTS.

Available data from five clinical phase II trials with finerenone in more than 2000 patients with HF and additional CKD and/or diabetes as well as in patients with diabetic kidney disease have demonstrated so far that neither hyperkalemia nor reductions in kidney function were limiting factors to its use. Recently, finerenone demonstrated a nominally improved outcome including death and $\mathrm{CV}$ hospitalization compared to eplerenone in a phase IIb trial with 1066 heart failure patients with reduced ejection fraction (HFrEF) and concomitant T2DM and/or CKD (Filippatos et al. 2016). Different dose strengths of finerenone were also investigated in 823 randomized patients with T2DM and diabetic kidney disease receiving standard of care (SoC) (i.e., ACEIs/ARBs) and either oncedaily (OD) finerenone or placebo (Bakris et al. 2015). Addition of finerenone to SoC resulted in dose-dependent, significant reductions in albuminuria at doses of 7.5, 10, 15 and $20 \mathrm{mg}$ after 90 days of treatment (Bakris et al. 2015). As nocturnal hypertension is common in patients with CKD, a post hoc study of finerenone for its effect on nocturnal hypertension in a subset of patients of the ARTS-DN study in whom ambulatory blood pressure measurement (ABPM) data were available were conducted. Patients with nocturnal hypertension showed a more pronounced reduction in nocturnal $\mathrm{BP}$ with finerenone (absolute change of $-9.5 \mathrm{mmHg}$ in $10 \mathrm{mg}$ and $-12.0 \mathrm{mmHg}$ in the $20 \mathrm{mg}$ dose group respectively) than under placebo $(-2.9 \mathrm{mmHg})$ at day 90 (Ruilope et al. 2016). However, only an appropriate trial

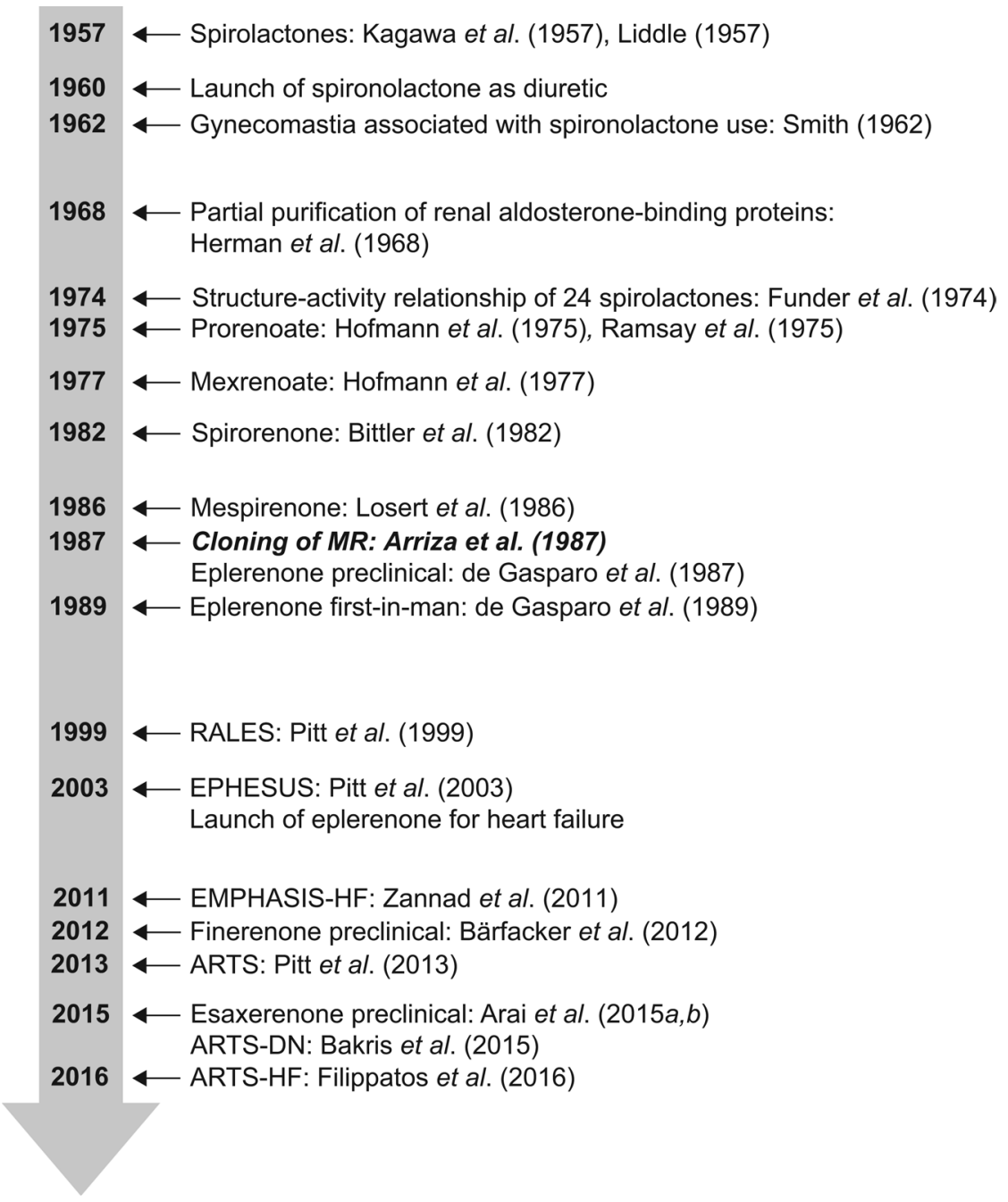

Figure 3

60 years of research and development on MRAs. The time bar highlights relevant publications on the discovery of MRAs or important clinical trial results with MRAs (RALES, EPHESUS, EMPHASIS-HF, ARTS, ARTS-DN and ARTS-HF) in a given year. Note that cloning of MR was at midway within the 60 years of R\&D on MRAs. http://joe.endocrinology-journals.org DOI: 10.1530/JOE-16-0600
(C) 2017 Society for Endocrinology Printed in Great Britain
Published by Bioscientifica Ltd 
among patients with essential hypertension should give definitive answers on the blood pressure-lowering potency and efficacy of finerenone in hypertensive patients.

Overall, the ARTS-HF and ARTS-DN studies demonstrated the best benefit-to-risk ratio at doses of $10-20 \mathrm{mg}$ finerenone OD. Accordingly, finerenone at daily doses of 10 and $20 \mathrm{mg}$ is currently being investigated in two large outcome trials in patients with DKD (FIGARO-DKD, NCT02545049 and FIDELIO-DKD and NCT02540993) (Table 1).

\section{Conclusions}

Joel Ménard once highlighted the remarkable timeframe of almost 45 years between the first clinical usage of spironolactone and the market launch of its steroidal successor eplerenone (Ménard 2004). This is even more remarkable when considering the structural similarities of these two compounds. A real paradigm change was initiated with the search for non-steroidalMRAs as these willultimately lead to compounds with different physicochemical, pharmacokinetic and eventually pharmacological properties in comparison to the 17-spirolactone-based MRAs including spironolactone and eplerenone. The long way of R\&D activities from the initial spirolactones to the current non-steroidal MRAs is briefly summarized in Fig. 3. The de Gasparo paper from 1989 summarizing the successful discovery story including the first-in-man study of eplerenone ended with two remarkable sentences: 'The clinical development of antialdosterones is lengthy and costly, and it is possible that the advantages of this treatment ... appears for many clinicians to be more theoretical than practical. If this is true, spironolactone would remain a unique compound, not only because it was the first anti-hormone used in clinical medicine, but also because it would have no successor' (de Gasparo et al. 1989). Now, almost 30 years later, it is clear that the development of any new cardiovascular drug has become a billion dollar investment, but the advantages of MRA use for a broad spectrum of patients are far beyond theoretical.

\section{Footnote}

This paper is part of a thematic review section on 30 Years of the Mineralocorticoid Receptor. The guest editors for this section were John Funder and Maria Christina Zennaro.

\section{Declaration of interest}

Dr Peter Kolkhof and Dr Lars Bärfacker are full time employees of Bayer AG.

\section{Funding}

This work did not receive any specific grant from any funding agency in the public, commercial, or not-for-profit sector.

\section{Acknowledgements}

The authors thank Verena Jilg for excellent technical assistance in the determination of the $\mathrm{IC}_{50}$ values of Table 2 and Dr Stuart Walsh for critical reading of the manuscript.

\section{References}

Aldactone NDA 2008 Aldactone, spironolactone tablets USP, NDA 12-151/ S-062, Pfizer, distributed by G.D. Searle LLC, LAB-0231-4.0, revised January 2008. New York, NY, USA: Pfizer Inc. (available at: http://www. accessdata.fda.gov/drugsatfda_docs/label/2008/012151s062lbl.pdf)

Amazit L, Le Billan F, Kolkhof P, Lamribet K, Viengchareun S, Fay MR, Khan JA, Hillisch A, Lombès M, Rafestin-Oblin ME, et al. 2015 Finerenone impedes aldosterone-dependent nuclear import of the mineralocorticoid receptor and prevents genomic recruitment of steroid receptor coactivator-1. Journal of Biological Chemistry 290 21876-21889. (doi:10.1074/jbc.M115.657957)

Arai K, Homma T, Morikawa Y, Ubukata N, Tsuruoka H, Aoki K, Ishikawa H, Mizuno M \& Sada T 2015a Pharmacological profile of CS-3150, a novel, highly potent and selective non-steroidal mineralocorticoid receptor antagonist. European Journal of Pharmacology 761 226-234. (doi:10.1016/j.ejphar.2015.06.015)

Arai K, Tsuruoka H \& Homma T $2015 b$ CS-3150, a novel non-steroidal mineralocorticoid receptor antagonist, prevents hypertension and cardiorenal injury in Dahl salt-sensitive hypertensive rats. European Journal of Pharmacology 769 266-273. (doi:10.1016/j.ejphar.2015.11.028)

Arai K, Morikawa Y, Ubukata N, Tsuruoka H \& Homma T 2016 CS3150, a novel nonsteroidal mineralocorticoid receptor antagonist, shows preventive and therapeutic effects on renal injury in deoxycorticosterone acetate/salt-induced hypertensive rats. Journal of Pharmacology and Experimental Therapeutics 358 548-557. (doi:10.1124/jpet.116.234765)

Arhancet GB, Woodard SS, Iyanar K, Case BL, Woerndle R, Dietz JD, Garland DJ, Collins JT, Payne MA, Blinn JR, et al. 2010 Discovery of novel cyanodihydropyridines as potent mineralocorticoid receptor antagonists. Journal of Medicinal Chemistry 53 5970-5978. (doi:10.1021/jm100506y)

Arriza JL, Weinberger C, Cerelli G, Glaser TM, Handelin BL, Housman DE \& Evans RM 1987 Cloning of human mineralocorticoid receptor complementary DNA: structural and functional kinship with the glucocorticoid receptor. Science 237 268-275. (doi:10.1126/ science.3037703)

Bakris GL, Agarwal R, Chan JC, Cooper ME, Gansevoort RT, Haller H, Remuzzi G, Rossing P, Schmieder RE, Nowack C, et al. 2015 Effect of finerenone on albuminuria in patients with diabetic nephropathy: a randomized clinical trial. Mineralocorticoid receptor antagonist tolerability study-diabetic nephropathy (ARTS-DN) study group. JAMA 314 884-894. (doi:10.1001/jama.2015.10081)

Bärfacker L, Kuhl A, Hillisch A, Grosser R, Figueroa-Pérez S, Heckroth H, Nitsche A, Ergüden JK, Gielen-Haertwig H, Schlemmer KH, et al. 2012 Discovery of BAY 94-8862: a nonsteroidal antagonist of the mineralocorticoid receptor for the treatment of cardiorenal diseases. ChemMedChem 7 1385-1403. (doi:10.1002/cmdc.201200081)

Bauersachs J 2013 The ARTS of third-generation mineralocorticoid receptor antagonists: achieving cardiovascular benefit with minimized renal side effects? European Heart Journal 34 2426-2428. (doi:10.1093/ eurheartj/eht235)

Bittler D, Hofmeister H, Laurent H, Nickisch K, Nickolson R, Petzoldt K \& Wiechert R 1982 Synthesis of spirorenone - a novel highly active http://joe.endocrinology-journals.org

DOI: $10.1530 / \mathrm{JOE}-16-0600$
() 2017 Society for Endocrinology Printed in Great Britain 
aldosterone antagonist. Angewandte Chemie 94 718. (doi:10.1002/ ange.19820940923)

Bomback AS, Kshirsagar AV \& Klemmer PJ 2009 Renal aspirin: will all patients with chronic kidney disease one day take spironolactone? Nature Clinical Practice Nephrology 5 74-75. (doi:10.1038/ncpneph1004)

Bramlage P, Swift SL, Thoenes M, Minguet J, Ferrero C \& Schmieder RE 2016 Non-steroidal mineralocorticoid receptor antagonism for the treatment of cardiovascular and renal disease. European Journal of Heart Failure 18 28-37. (doi:10.1002/ejhf.444)

Brandish PE, Fraley ME, Hershey JC \& Steen JT 2009 Mineralocorticoid Receptor Modulators. Patent WO 2009078934 A1. Kenilworth, NJ, USA: Merck \& Co., Inc. (available at: https://www.google.com/patents/ WO2009078934A1)

Brilla CG, Pick R, Tan LB, Janicki JS \& Weber KT 1990 Remodeling of the rat right and left ventricles in experimental hypertension. Circulation Research 67 1355-1364. (doi:10.1161/01.RES.67.6.1355)

Casals-Stenzel J, Buse M, Wambach G \& Losert W 1984 The renal action of spirorenone and other $6 \beta, 7 \beta ; 15 \beta, 16 \beta$-dimethylene-17spirolactones, a new type of steroidal aldosterone antagonists. Arzneimittelforschung 34 241-246.

Cella JA \& Kagawa CM 1957 Steroidal lactones. Journal of the American Chemistry Society 79 4808-4809. (doi:10.1021/ja01574a058)

Cella JA \& Tweit RC 1959 Steroidal aldosterone blockers. II. Journal of Organic Chemistry 24 1109-1110. (doi:10.1021/jo01090a019)

Chien YW, Hofmann LM, Lambert HJ \& Tao LC 1976 Binding of spirolactones to human plasma proteins. Journal of Pharmaceutical Sciences 65 1337-1340. (doi:10.1002/jps.2600650919)

Claire M, Rafestin-Oblin ME, Michaud A, Roth-Meyer C \& Corvol P 1979 Mechanism of action of a new antialdosterone compound, prorenone. Endocrinology 104 1194-1200. (doi:10.1210/endo-104-4-1194)

Cook CS, Hauswald CL, Schoenhard GL, Piper CE, Patel A, Radzialowski FM, Hribar JD, Aksamit W, Finnegan P, Bible RH, et al. 1988 Difference in metabolic profile of potassium canrenoate and spironolactone in the rat: mutagenic metabolites unique to potassium canrenoate. Archives of Toxicology 61 201-212. (doi:10.1007/BF00316635)

Cook CS, Berry LM, Bible RH, Hribar JD, Hajdu E \& Liu NW 2003 Pharmacokinetics and metabolism of [14C]eplerenone after ora administration to humans. Drug Metabolism and Disposition 31 1448-1455. (doi:10.1124/dmd.31.11.1448)

Corvol P, Michaud A, Menard J, Freifeld M \& Mahoudeau J 1975 Antiandrogenic effect of spirolactones: mechanism of action. Endocrinology 97 52-58.

Corvol P, Claire M, Oblin ME, Geering K \& Rossier B 1981 Mechanism of the antimineralocorticoid effects of spirolactones. Kidney International 20 1-6. (doi:10.1038/ki.1981.97)

Dahlöf CG, Lundborg P, Persson BA \& Regårdh CG 1979 Re-evaluation of the antimineralocorticoid effect of the spironolactone metabolite, canrenone, from plasma concentrations determined by a new high-pressure liquid-chromatographic method. Drug Metabolism and Disposition 7 103-107.

de Gasparo M, Joss U, Ramjoué HP, Whitebread SE, Haenni H, Schenkel L, Kraehenbuehl C, Biollaz M, Grob J \& Schmidlin J 1987 Three new epoxy-spirolactone derivatives: characterization in vivo and in vitro. Journal of Pharmacology and Experimental Therapeutics 240 650-656.

de Gasparo M, Whitebread SE, Preiswerk G, Jeunemaitre X, Corvol P \& Menard J 1989 Antialdosterones: incidence and prevention of sexual side effects. Journal of Steroid Biochemistry 32 223-227. (doi:10.1016/0022-4731(89)90169-6)

Dinsdale C, Wani M, Steward J \& O'Mahony MS 2005 Tolerability of spironolactone as adjunctive treatment for heart failure in patients over 75 years of age. Age and Ageing 34 395-398. (doi:10.1093/ageing/afi104)

Dorrance AM 2008 Stroke therapy: is spironolactone the holy grail? Endocrinology 149 3761-3763. (doi:10.1210/en.2008-0724)

Drug and Therapeutic Bulletin 1988 Spironolactone: no longer for hypertension. In Drug and Therapeutic Bulletin, vol. 26, p 88. Eds Andrew Herxheimer. London, UK: Consumers' Association Ltd.
Ergueden JK, Kolkhof P, Sandner P, Kuhl A, Stasch JP, Pook E \& Schlemmer KH 2005 Fluorenone 1,4,-Dihydropyridin Derivatives. Patent WO 2005087740 A1. Leverkusen, Germany: Bayer Healthcare AG. (available at: https://google.com/patents/WO2005087740A1)

Fagart J, Hillisch A, Huyet J, Bärfacker L, Fay M, Pleiss U, Pook E, Schäfer S, Rafestin-Oblin ME \& Kolkhof P 2010 A new mode of mineralocorticoid receptor antagonism by a potent and selective nonsteroidal molecule. Journal of Biological Chemistry $\mathbf{2 8 5}$ 29932-29940. (doi:10.1074/jbc.M110.131342)

Feinfeld DA \& Carvounis CP 1978 Fatal hyperkalemia and hyperchloremic acidosis. Association with spironolactone in the absence of renal impairment. JAMA 240 1516. (doi:10.1001/ jama.1978.03290140058027)

Feldman D, Funder JW \& Edelman IS 1972 Subcellular mechanism in the action of the adrenal steroids. American Journal of Medicine $\mathbf{5 3}$ 545-560. (doi:10.1016/0002-9343(72)90152-0)

Filippatos G, Anker SD, Böhm M, Gheorghiade M, Køber L, Krum H, Maggioni AP, Ponikowski P, Voors AA, Zannad F, et al. 2016 A randomized controlled study of finerenone vs eplerenone in patients with worsening chronic heart failure and diabetes mellitus and/ or chronic kidney disease. European Heart Journal 37 2105-2114. (doi:10.1093/eurheartj/ehw132)

Fitzgerald N \& Fitzgerald JD 2009 Trails of discovery: aldosterone antagonists: a model of translational medicine. Dialogues in Cardiovascular Medicine 14 119-125.

Funder JW 2005 Mineralocorticoid receptors: distribution and activation. Heart Failure Reviews 10 15-22. (doi:10.1007/s10741-005-2344-2)

Funder JW, Feldman D \& Edelman IS 1972 Specific aldosterone binding in rat kidney and parotid. Journal of Steroid Biochemistry 3 209-218. (doi:10.1016/0022-4731(72)90052-0)

Funder JW, Feldman D, Highland E \& Edelman IS 1974 Molecular modifications of anti-aldosterone compounds: effects on affinity of spirolactones for renal aldosterone receptors. Biochemical Pharmacology 23 1493-1501. (doi:10.1016/0006-2952(74)90386-4)

Funder JW, Mercer J \& Hood J 1976 SC 23992: radioreceptor assays for therapeutic and side effects. Clinical Science and Molecular Medicine Supplements 51 333s-334s. (doi:10.1042/cs051333s)

Funder JW, Pearce PT, Smith R \& Campbell J 1989 Vascular type I aldosterone binding sites are physiological mineralocorticoid receptors. Endocrinology 125 2224-2226.

Gardiner P, Schrode K, Quinlan D, Martin BK, Boreham DR, Rogers MS, Stubbs K, Smith M \& Karim A 1989 Spironolactone metabolism: steady-state serum levels of the sulfur-containing metabolites. Journal of Clinical Pharmacology 29 342-347.

Garthwaite SM \& McMahon EG 2004 The evolution of aldosterone antagonists. Molecular and Cellular Endocrinology 217 27-31. (doi:10.1016/j.mce.2003.10.005)

Geller DS, Farhi A, Pinkerton N, Fradley M, Moritz M, Spitzer A, Meinke G, Tsai FT, Sigler PB \& Lifton RP 2000 Activating mineralocorticoid receptor mutation in hypertension exacerbated by pregnancy. Science 289 119-123. (doi:10.1126/science.289.5476.119)

Gochman N \& Gantt CL 1962 A fluorimetric method for the determination of a major spironolactone (Aldactone) metabolite in human plasma. Journal of Pharmacology and Experimental Therapeutics 135 312-316.

Gomez-Sanchez EP 2016 Third-generation mineralocorticoid receptor antagonists: why do we need a fourth? Journal of Cardiovascular Pharmacology 67 26-38. (doi:10.1097/FJC.0000000000000329)

Gomez-Sanchez EP, Fort C \& Thwaites D 1992 Central mineralocorticoid receptor antagonism blocks hypertension in Dahl S/JR rats. American Journal of Physiology 262 E96-E99.

Grob J, Boillaz M, Schmidlin J, Wehrli H, Wielanol P, Fuhrer H, Rihs G, Joss U, de Gasparo M, Haenni H, et al. 1997 Steroidal aldosterone antagonists: increased selectivity of 9a1 11-epoxy derivatives. Helvetica Chimica Acta 80 566-585. (doi:10.1002/ hlca.19970800220) http://joe.endocrinology-journals.org

DOI: 10.1530/JOE-16-0600
() 2017 Society for Endocrinology Printed in Great Britain 
Grune J, Benz V, Brix S, Salatzki J, Blumrich A, Höft B, Klopfleisch R, Foryst-Ludwig A, Kolkhof P \& Kintscher U 2016 Steroidal and nonsteroidal mineralocorticoid receptor antagonists cause differential cardiac gene expression in pressure overload-induced cardiac hypertrophy. Journal of Cardiovascular Pharmacology 67 402-411. (doi:10.1097/FJC.0000000000000366)

Haller H, Bertram A, Stahl K \& Menne J 2016 Finerenone: a new mineralocorticoid receptor antagonist without hyperkalemia: an opportunity in patients with CKD? Current Hypertension Reports 1841 . (doi:10.1007/s11906-016-0649-2)

Herman E \& Rado J 1966 Fatal hyperkalemic paralysis associated with spironalactone. Observation on a patient with severe renal disease and refractory edema. Archives of Neurology 15 74-77. (doi:10.1001/ archneur.1966.00470130078008)

Herman TS, Fimognari GM \& Edelman IS 1968 Studies on renal aldosterone-binding proteins. Journal of Biological Chemistry 243 3849-3856.

Hertz R \& Tullner WW 1958 Progestational activity of certain steroid17-spirolactones. Proceedings of the Society for Experimental Biology and Medicine 99 451-452. (doi:10.3181/00379727-99-24380)

Hofmann LM, Chinn LJ, Pedrera HA, Krupnick MI \& Suleymanov OD 1975 Potassium prorenoate: a new steroidal aldosterone antagonist. Journal of Pharmacology and Experimental Therapeutics 194 450-456.

Hofmann LM, Weier RM, Suleymanov OD \& Pedrera HA 1977 Mexrenoate potassium: a steroidal aldosterone antagonist and antihypertensive. Journal of Pharmacology and Experimental Therapeutics 201 762-768.

Hu X, Li S, McMahon EG, Lala DS \& Rudolph AE 2005 Molecular mechanisms of mineralocorticoid receptor antagonism by eplerenone. Mini-Reviews in Medicinal Chemistry 5 709-718. (doi:10.2174/1389557054553811)

Huffman DH, Kampmann JP, Hignite CE \& Azarnoff DL 1978 Gynecomastia induced in normal males by spironolactone. Clinical Pharmacology and Therapeutics 24 465-473. (doi:10.1002/cpt1978244465)

Inspra Prescribing Information 2002 INSPRA (eplerenone) tablets: highlights of prescribing information. Silverspring, MD, USA: FDA, US Food and Drug Administration (available at: http://www. accessdata.fda.gov/drugsatfda_docs/label/2008/021437s006lbl.pdf)

Jeunemaitre X, Chatellier G, Kreft-Jais C, Charru A, DeVries C, Plouin PF, Corvol P \& Menard J 1987 Efficacy and tolerance of spironolactone in essential hypertension. American Journal of Cardiology 60 820-825. (doi:10.1016/0002-9149(87)91030-7)

Juurlink DN, Mamdani MM, Lee DS, Kopp A, Austin PC, Laupacis A \& Redelmeier DA 2004 Rates of hyperkalemia after publication of the randomized aldactone evaluation study. New England Journal of Medicine 351 543-551. (doi:10.1056/NEJMoa040135)

Kagawa CM, Cella JA \& Van Arman CG 1957 Action of new steroids in blocking effects of aldosterone and desoxycorticosterone on salt. Science 126 1015-1016. (doi:10.1126/science.126.3281.1015)

Kagawa CM, Sturtevant FM \& Van Arman CG 1959 Pharmacology of a new steroid that blocks salt activity of aldosterone and desoxycorticosterone. Journal of Pharmacology and Experimental Therapy 126 123-130.

Karim A 1978 Spironolactone: disposition, metabolism, pharmacodynamics, and bioavailability. Drug Metabolism Reviews $\mathbf{8}$ 151-188. (doi:10.3109/03602537808993782)

Karim A \& Brown EA 1972 Isolation and identification of novel sulfurcontaining metabolites of spironolactone (Aldactone). Steroids $\mathbf{2 0}$ 41-62. (doi:10.1016/0039-128X(72)90117-1)

Kolkhof P \& Borden SA 2012 Molecular pharmacology of the mineralocorticoid receptor: prospects for novel therapeutics. Molecular and Cellular Endocrinology 350 310-317. (doi:10.1016/j. mce.2011.06.025)

Kolkhof P, Delbeck M, Kretschmer A, Steinke W, Hartmann E, Bärfacker L, Eitner F, Albrecht-Küpper B \& Schäfer S 2014 Finerenone, a novel selective nonsteroidal mineralocorticoid receptor antagonist protects

http://joe.endocrinology-journals.org

DOI: $10.1530 / J O E-16-0600$ (c) 2017 Society for Endocrinology Printed in Great Britain from rat cardiorenal injury. Journal of Cardiovascular Pharmacology 64 69-78. (doi:10.1097/FJC.0000000000000091)

Kolkhof P, Nowack C \& Eitner F 2015 Nonsteroidal antagonists of the mineralocorticoid receptor. Current Opinions in Nephrology and Hypertension 24 417-424. (doi:10.1097/MNH.0000000000000147)

Kolkhof P, Jaisser F, Kim SY, Filippatos G, Nowack C \& Pitt B 2016 Steroidal and novel non-steroidal mineralocorticoid receptor antagonists in heart failure and cardiorenal diseases: comparison at bench and bedside. Handbook of Experimental Pharmacology [in press]. (doi:10.1007/164_2016_76)

Krause W, Sack C \& Seifert W 1983 Pharmacokinetics of the new aldosterone antagonist, spirorenone, in healthy volunteers after single and repeated daily doses. European Journal of Clinical Pharmacology 25 231-236. (doi:10.1007/BF00543796)

Landau RL \& Lugibihl K 1958 Inhibition of the sodium-retaining influence of aldosterone by progesterone. Journal of Clinical Endocrinology and Metabolism 18 1237-1245. (doi:10.1210/jcem-18-11-1237)

Landau RL, Bergenstal DM, Lugibihl K \& Kascht ME 1955 The metabolic effects of progesterone in man. Journal of Clinical Endocrinology and Metabolism 15 1194-1215. (doi:10.1210/jcem-15-10-1194)

Laurent H, Bittler D, Hofmeister H, Nickisch K, Nickolson R, Petzoldt K \& Wiechert R 1983 Synthesis and activities of anti-aldosterones. Journal of Steroid Biochemistry 19 771-776. (doi:10.1016/0022-4731(83)90010-9)

Liddle GW 1957 Sodium diuresis induced by steroidal antagonists of aldosterone. Science 126 1016-1018. (doi:10.1126/ science.126.3281.1016)

Liddle GW 1958 Aldosterone antagonists. Archives of Internal Medicine 102 998-1004. (doi:10.1001/archinte.1958.00260230144018)

Liu LC, Schutte E, Gansevoort RT, van der Meer P \& Voors AA 2015 Finerenone: third-generation mineralocorticoid receptor antagonist for the treatment of heart failure and diabetic kidney disease. Expert Opinions on Investigational Drugs 24 1123-1135. (doi:10.1517/135437 84.2015.1059819)

Losert W, Casals-Stenzel J \& Buse M 1985 Progestagens with antimineralocorticoid activity. Drug Research 35 459-471.

Losert W, Bittler D, Buse M, Casals-Stenzel J, Haberey M, Laurent H, Nickisch K, Schillinger E \& Wiechert R 1986 Mespirenone and other 15,16-methylene-17-spirolactones, a new type of steroidal aldosterone antagonists. Arzneimittelforschung 36 1583-1600.

Lumb G, Newberne P, Rust JH \& Wagner B 1978 Effects in animals of chronic administration of spironolactone - a review. Journal of Environmental Pathology and Toxicology 1 641-660.

Mayer DG, Bode G \& Radzialowski FM 1988 Toxikologisches profil von spironolacton und kaliumcanrenoat. In Therapie Mit AldosteronAntagonisten. Ed E Mutschler. München-Wien-Baltimore: Urban \& Scharzenberg, ISBN 3-541-12741-4.

McInnes GT, Shelton JR, Harrison IR, Perkins RM \& Palmer RF 1982 Comparison of prorenoate potassium and spironolactone after repeated doses and steady state plasma levels of active metabolites. British Journal of Clinical Pharmacology 13 187-194. (doi:10.1111/j.1365-2125.1982.tb01354.x)

McInnes GT, Harrison IR, Shelton JR, Perkins RM \& Clarke JM 1984 Relative potency of prorenoate potassium and spironolactone in attenuating diuretic induced hypokalaemia. British Journal of Clinical Pharmacology 18 169-174. (doi:10.1111/j.1365-2125.1984.tb02449.x)

Ménard J 2004 The 45-year story of the development of an antialdosterone more specific than spironolactone. Molecular and Cellular Endocrinology 217 45-52. (doi:10.1016/j.mce.2003.10.008)

Merkus FW, Overdiek JW, Cilissen J \& Zuidema J. 1983 Pharmacokinetics of spironolactone after a single dose: evaluation of the true canrenone serum concentrations during 24 hours. Clinical and Experimental Hypertension: Part A, Theory and Practice 5 239-248. (doi:10.3109/10641968309048824)

Muhn P, Krattenmacher R, Beier S, Elger W \& Schillinger E 1995 Drospirenone: a novel progestogen with antimineralocorticoid and antiandrogenic activity. Pharmacological characterization 
in animal models. Contraception 51 99-110. (doi:10.1016/00107824(94)00015-O)

Naegele M, Hernandez AF \& Ruschitzka F 2016 Finerenone in heart failure: walking a fine line. European Heart Journal 37 2115-2117. (doi:10.1093/eurheartj/ehw155)

Oppermann JA, Piper C \& Gardiner P 1988 Spironolactone and potassium canrenoate - despite chemical similarities, differing metabolism accounts for different toxicological findings in animals. In Therapie Mit Aldosteron-Antagonisten. Ed E Mutschler. München-WienBaltimore: Urban \& Scharzenberg, ISBN 3-541-12741-4.

Overdiek HW \& Merkus FW 1987 The metabolism and biopharmaceutics of spironolactone in man. Reviews on Drug Metabolism and Drug Interactions 5 273-302. (doi:10.1515/DMDI.1987.5.4.273)

Parthasarathy HK, Ménard J, White WB, Young WF Jr, Williams GH, Williams B, Ruilope LM, McInnes GT, Connell JM \& MacDonald TM 2011 A double-blind, randomized study comparing the antihypertensive effect of eplerenone and spironolactone in patients with hypertension and evidence of primary aldosteronism. Journal of Hypertension 29 980-990. (doi:10.1097/HJH.0b013e3283455ca5)

Pearce P \& Funder JW 1987 High affinity aldosterone binding sites (type I receptors) in rat heart. Clinical and Experimental Pharmacology and Physiology 14 859-866. (doi:10.1111/j.1440-1681.1987.tb02422.x)

Pitt B, Zannad F, Remme WJ, Cody R, Castaigne A, Perez A, Palensky J \& Wittes J 1999 The effect of spironolactone on morbidity and mortality in patients with severe heart failure. Randomized Aldactone Evaluation Study Investigators. New England Journal of Medicine 341 709-717. (doi:10.1056/NEJM199909023411001)

Pitt B, Remme W, Zannad F, Neaton J, Martinez F, Roniker B, Bittman R, Hurley S, Kleiman J \& Gatlin M 2003 Eplerenone, a selective aldosterone blocker, in patients with left ventricular dysfunction after myocardial infarction. New England Journal of Medicine 348 1309-1321. (doi:10.1056/NEJMoa030207)

Pitt B, Filippatos G, Gheorghiade M, Kober L, Krum H, Ponikowski P, Nowack C, Kolkhof P, Kim SY \& Zannad F 2012 Rationale and design of ARTS: a randomized, double-blind study of BAY 94-8862 in patients with chronic heart failure and mild or moderate chronic kidney disease. European Journal of Heart Failure 14 668-675. (doi:10.1093/eurjhf/hfs061)

Pitt B, Kober L, Ponikowski P, Gheorghiade M, Filippatos G, Krum H, Nowack C, Kolkhof P, Kim SY \& Zannad F 2013 Safety and tolerability of the novel non-steroidal mineralocorticoid receptor antagonist BAY 94-8862 in patients with chronic heart failure and mild or moderate chronic kidney disease: a randomized, double-blind trial. European Heart Journal 34 2453-2463. (doi:10.1093/eurheartj/eht187)

Pongpaew C, Songkhla RN \& Kozam RL 1973 Hyperkalemic cardiac arrhythmia secondary to spironolactone. Chest 63 1023-1025. (doi:10.1378/chest.63.6.1023)

Ramsay L, Harrison I, Shelton J \& Tidd M 1975 Relative potency of prorenoate and spironolactone in normal man. Clinical Pharmacology and Therapeutics 18 391-400. (doi:10.1002/cpt1975184391)

Rocha R, Rudolph AE, Frierdich GE, Nachowiak DA, Kekec BK, Blomme EA, McMahon EG \& Delyani JA 2002 Aldosterone induces a vascular inflammatory phenotype in the rat heart. American Journal of Physiology: Heart and Circulatory Physiology 283 H1802-H1810. (doi:10.1152/ajpheart.01096.2001)

Ruilope LM, Nowack C \& Bakris GL 2016 Masked and nocturnal hypertension in the ARTS-DN ABPM sub-study with finerenone. Journal of the American Society of Hypertension 10 (Supplement 1) e7. (doi:10.1016/j.jash.2016.06.021)
Sadée W, Dagcioglu M \& Schröder R 1973 Pharmacokinetics of spironolactone, canrenone and canrenoate-K in humans. Journal of Pharmacology and Experimental Therapy 185 686-695.

Seifert W, Groß C, Krais T \& Müller U 1982 Pharmacological investigation on the effect of ZK 35973 (spirorenone INN), a new aldosterone antagonist in man. Acta Endocrinologica 99 (Supplement 246) abstract 106. (doi:10.1530/acta.0.0990III)

Selye H 1942 Production of nephrosclerosis by overdosage with desoxycorticosterone acetate. Canadian Medical Association Journal 47 515-519.

Selye H 1946 The general adaptation syndrome and the diseases of adaptation. Journal of Clinical Endocrinology and Metabolism 6 117-230. (doi:10.1210/jcem-6-2-117)

Selye H 1955 Anticortisol action of aldosterone. Science 121 368-369. (doi:10.1126/science.121.3141.368)

Selye H 1960 Protection by a steroid-spirolactone against certain types of cardiac necroses. Proceedings of the Society for Experimental Biology and Medicine 104 212-213. (doi:10.3181/00379727-104-25782)

Sica DA 2005 Pharmacokinetics and pharmacodynamics of mineralocorticoid blocking agents and their effects on potassium homeostasis. Heart Failure Reviews 10 23-29. (doi:10.1007/s10741-005-2345-1)

Sturtevant FM 1992 A lesson to be gained from basic research programs. Current Contents 359.

Smith WG 1962 Spironolactone and gynaecomastia. Lancet 280886. (doi:10.1016/S0140-6736(62)90668-2)

Svensson M, Gustafsson F, Galatius S, Hildebrandt PR \& Atar D 2004 How prevalent is hyperkalemia and renal dysfunction during treatment with spironolactone in patients with congestive heart failure? Journal of Cardiac Failure 10 297-303. (doi:10.1016/j.cardfail.2003.10.012)

Taylor FF \& Faloon WW 1959 The role of potassium in the natriuretic response to a steroidal lactone (SC-9420). Journal of Clinical Endocrinology and Metabolism 19 1683-1687. (doi:10.1210/jcem-19-12-1683)

Thorn GW \& Engel LL 1938 The effect of sex hormones on the renal excretion of electrolytes. Journal of Experimental Medicine 68 299-312. (doi:10.1084/jem.68.3.299)

Thosar SS, Gokhale RD \& Tolbert DS 2003 Immediate Release Eplerenone Compositions. Patent US 6558707 B1. Skokie, IL, USA: G.D. Searle \& Co. (available at: https://www.google.com/patents/US6558707)

Ulmann A, Bertagna C, Le Go A, Husson JM, Tache A, Sassano P, Menard J \& Corvol P 1985 Assessment of the antimineralocorticoid effect of RU 28318 in healthy men with induced exogenous and endogenous hypermineralocorticism. European Journal of Clinical Pharmacology $\mathbf{2 8}$ 531-535. (doi:10.1007/BF00544063)

Vonder Haar TA \& Miller M 1977 Warning: your prescription may be dangerous to your health. In New York Magazine, pp 46-57. New York, NY, USA: New York Media, LLC.

Weinberger MH, Roniker B, Krause SL \& Weiss RJ 2002 Eplerenone, a selective aldosterone blocker, in mild-to-moderate hypertension. American Journal of Hypertension 15 709-716. (doi:10.1016/S08957061(02)02957-6)

Yang J \& Young MJ 2016 Mineralocorticoid receptor antagonistspharmacodynamics and pharmacokinetic differences. Current Opinions in Pharmacology 27 78-85. (doi:10.1016/j. coph.2016.02.005)

Zannad F, McMurray JJ, Krum H, van Veldhuisen DJ, Swedberg K, Shi H, Vincent J, Pocock SJ \& Pitt B 2011 Eplerenone in patients with systolic heart failure and mild symptoms. New England Journal of Medicine 364 11-21. (doi:10.1056/NEJMoa1009492)

Received in final form 27 January 2017

Accepted 21 February 2017 http://joe.endocrinology-journals.org

DOI: 10.1530/JOE-16-0600
๑) 2017 Society for Endocrinology Printed in Great Britain
Published by Bioscientifica Ltd. 